\title{
Synthesis and physicochemical properties of polysaccharides by Gluconobacter oxydans with glycosyltransferase activity
}

\author{
Ji Hye Jeong ${ }^{\ddagger}$, Ji Yeong Park $^{\ddagger}$, Hyun Ji Lee, Ji-Ho Choi, Shin-Yeong Park, \\ Chan Soon Park, Bo-Ram Park* \\ Department of Agro-Food Resources, National Institute of Agricultural Sciences, Rural Development Administration, \\ Jeonju 55365, Korea
}

\section{Gluconobacter oxydans의 당 전이효소 활성을 이용한 다당류의 제조 및 배양액의 품질 특성}

\author{
정지혜 ${ }^{\ddagger}$ - 박지영 ${ }^{\ddagger}$ 이현지 · 최지호 · 박신영 · 박찬순 · 박보람* \\ 국립농업과학원 농식품자원부 발효가공식품과
}

\begin{abstract}
Dextran, a homologous polysaccharide with the main chain of glucose units composed by an $\alpha-1,6$ glycosidic bond, is synthesized from dextrin by dextran-dextrinase (DDase), a transglucosidase, derived from acetic acid bacteria Gluconobacter oxydans and lactic acid bacteria (LAB). The effective culture conditions were examined for producing dextran via bio-conversion with acetic acid bacteria (AAB) demonstrating DDase activity in various medium compositions during 0 to 7 days with or without glycerol addition $(2 \%, v / v)$ and different degrees of dextrin polymerization (D.E.) based on the addition level $(1,5 \%$, w/v). On day 7 , the $G$. oxydans growth was almost tripled in presence of glycerol as observed via a cell growth curve (OD). After culturing for 7 days, the pH decreased from 6 to 3.1-3.5, and the acidity increased from $0.12 \%$ to $0.4-0.62 \%$, depending on the dextrin D.E. and the addition level. The reducing sugar decreased continuously. The medium containing $5 \%$ dextrin showed shear-thinning characteristics. The apparent viscosity of the 5\% dextrin DE4-7 culture solution was $5.6 \mathrm{mPa} \cdot \mathrm{s}$, which was similar to that of the $20 \%$ dextran aqueous solution. The analysis of constituent saccharides contained in the culture medium (HPAEC-PAD) showed a substance with a high degree of polymerization. ${ }^{1} \mathrm{H}-\mathrm{NMR}$ analysis showed that $\alpha-1,6$ glycosidic bond existed as the intermolecular bond of this substance. Therefore, efficient production of dextran was possible by culturing in a medium containing $5 \%$ dextrin and glycerol during culture of AAB.
\end{abstract}

Key words : acetic acid bacteria, dextran dextrinase (DDase), culturing media properties, dextran, Gluconobacter oxydans

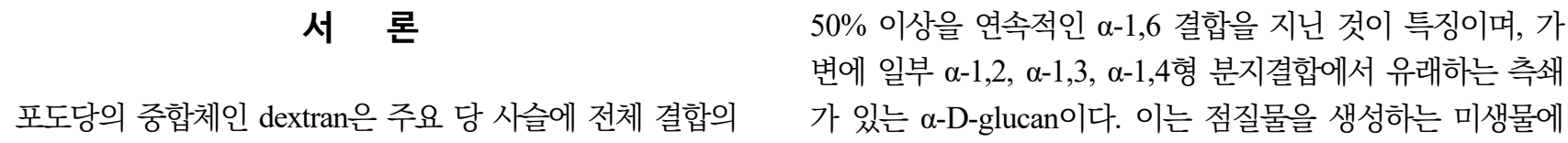

*Corresponding author. E-mail : bboram27@korea.kr, Phone :+82-63-238-3642, Fax : +82-63-238-3843

${ }^{\ddagger}$ These authors contributed equally to this work.

Received 18 January 2021; Revised 10 April 2021; Accepted 28 April 2021.

Copyright (c) The Korean Society of Food Preservation.

This is an Open Access article distributed under the terms of the Creative Commons Attribution Non-Commercial License (http://creativecommons.org/licenses/by-nc/4.0) which permits unrestricted non-commercial use, distribution, and reproduction in any medium, provided the original work is properly cited. 
서 분리된 biopolymer(Naessens 등, 2005a)로서, 분자량, 구성 당의 종류, 결합 순서 - 양식 · 위치 및 분지결합 유무에 따라 독특한 물성과 생리활성 등 다양한 기능성을 나타낸다(Son 등, 1996). Dextran은 주로 유산균(Leuconostoc mesenteroides)의 dextran sucrase(DSase; EC 2.4.1.5) 효소에 의해 sucrose 내 glucose 잔기의 transglucosylation 작용으로 합성된 고분자 다당류로 알려져 있다(Lindberg와 Svensson, 1968; Robyt와 Walseth, 1979). 이 외에도 맥주의 점성 물질을 생성하는 초 산균(Gluconobacter oxydans)에 의한 dextran 생성이 보고되 었으며(Hehre와 Hamilton, 1949), dextran이 유래한 미생물 및 효소에 따라 분지결합 형태 및 함량이 다른 것으로 알려져 있다(Leathers, 2002). 일반적으로 고분자 다당류는 젤 형성 능, 유화 안정력 및 필름형성능 등의 광범위한 기능 특성으로 인해 수용액의 rheology적 특성을 크게 변화시키므로 점도는 미용 및 의료용 소재 등 다양한 산업 적용 시 중요한 정보를 제공한다(Jang, 2019).

G. oxydans 유래 dextran dextrinase(DDase; EC2.4.1.2)는 maltodextrin 내 $\alpha-1,4$ glycosidic linkage로 결합된 glucosyl unit를 donor molecule에서 acceptor molecule로 전달하는 transglucosidase의 활성을 통하여, $\alpha-1,6$ glycosidic linked chain 형태로 결합된 당전이 생성물인 dextran을 생성한다(Naessens와 Vandamme, 2001). G. oxydans는 Acetobacteraceae과에 속하는 그람 음성균으로 산화 · 발효과정에서 광범위한 탄수화물 이 용능 및 알코올의 불완전한 산화능을 가지며(Prust 등, 2005), cellulose, dextran과 같은 biopolymer 생산 및 transglucosylation 효소(DDase) 생산 관점에서 잠재적 능력이 있는 균주 로 보고되고 있다(De Muynck 등, 2007). G. oxydans 유래의 기능성 다당류 생산을 위한 노력의 일환으로, DDase 효소 작용기전(Hehre, 1951; Yamamoto 등, 1993), G. oxydans ATCC 11894 유래의 DDase 효소 정제 및 생화학적 특성 (Suzuki 등, 1999; Suzuki 등, 2000) 및 기질 특이성(Naessens 와 Vandamme, 2001; Yamamoto 등, 1994) 등에 대한 다양 한 연구가 진행되었다. 그리고 G. oxydans 유래의 세포 내 DDase 회수 최적화를 위한 탄소원 및 질소원 탐색 연구에서 glycerol, mannitol, mycological peptone이 효소 활성도 및 생육 증진에 효과가 있으며(Naessens 등, 2004), dehydroxyacetone 생산 시 glycerol의 농도에 따라 농도 의존적으로 $G$. oxydans의 생육이 증가한다고 알려져 있다(Gaetgens 등, 2007).

G. oxydans는 식품소재 생산 측면에서 잠재력이 매우 높 은 균주로, 이를 활용하여 제약 - 식품 · 화학 업종에 폭넓게 적용되는 기능성 다당류인 dextran을 생산하고자 산업적으로 생물공학 기술을 적용하고 있다(Mao 등, 2012). 하지만 대사 공학 및 효소공학 방법을 적용할 경우, 식품 소재로 사용하기
위해서는 안전성 검증 등의 이유로 오랜 연구기간이 필요하 다는 한계가 있다. 최근, 목적 물질을 생산하는 미생물의 최 적배양을 통하여 배양액 내 생성 물질을 이용하는 생물전환 방법에 대한 관심이 증가하고 있으나, 국내에서는 당전이 활 성이 있는 G. oxydans의 생물전환을 통해 dextrin을 기능성 다당류인 dextran으로 전환하는 연구가 부족한 실정이다. 해 외 사례로는 Weisella confusa 균주의 $10 \%(\mathrm{w} / \mathrm{v})$ sucrose 함 유 MRS 배지 배양으로 dextran 전환 및 물성특성 연구 사례 가 보고되어 있다(Netsopa 등, 2018).

따라서 본 연구에서는 G. oxydans의 배양 중 전구체로 작 용하는 maltodextrin의 중합도, 첨가수준 및 다가알코올류 첨 가에 따른 생육특성과, 배양상등액으로부터 회수된 다당류의 특성 분석을 통하여 G. oxydans의 효과적인 생물전환 작용을 유도하는 배양조건을 탐색하고자 하였고, G. oxydans 균주를 이용한 maltodextrin으로부터 dextran으로의 생물전환의 기 초 자료를 확보하고자 하였다.

\section{재료 및 방법}

\section{실험재료}

본 실험에서 구성당 분석을 위해 사용된 표준물질 fructose $(\mathrm{F})$, glucose $(\mathrm{G})$, sucrose $(\mathrm{S})$, nigerose $(\mathrm{N})$, maltose(M2), kojibiose $(\mathrm{K})$, isomaltose(IM2), maltotriose(M3), panose(P), isomaltotriose (IM3), maltoheptaose(M7)은 Sigma-Aldrich(St. Louis, Mo, USA), maltotetraose(M4), isomaltotetraose(IM4), maltopentaose (M5), isomaltopentaose(IM5), maltohexaose(M6)는 TRC(Toronto, Canada), isomaltohexaose(IM6), isomaltoheptaose(IM7)는 Omicron(Amherst, MA, USA), dextran( $\mathrm{Mw}=40,000)$ 은 TCI (Tokyo, Japan)에서 HPLC-grade 시약을 구입하여 사용하였다.

\section{균주 및 배양조건}

본 연구에 사용된 초산균 표준균주는 국립농업과학원 미 생물은행(KACC)으로부터 Gluconobacter oxydans을 분양받았 으며, 초산균 배양배지는 acetic acid bacterium(AAB; peptone $5 \mathrm{~g} / \mathrm{L}$, yeast extract $5 \mathrm{~g} / \mathrm{L}$, glucose $5 \mathrm{~g} / \mathrm{L}, \mathrm{MgSO}_{4} \cdot 7 \mathrm{H}_{2} \mathrm{O}$ $1 \mathrm{~g} / \mathrm{L}, \mathrm{pH}$ 6.6-7.0) media를 사용하였다. 다당류 제조를 위한 배양배지는 $\mathrm{AAB}$ media에 $1 \%, 5 \%$ maltodextrin(dextrose equivalent 4.0-7.0, MD1, Sigma-Aldrich) 또는 $1 \%, 5 \%$ maltodextrin(dextrose equivalent 13.0-17.0, MD2)을 첨가하 여 제조하였다. Naessens 등(2005b)에 따르면, 배지 내 다가 알코올(glycerol)의 첨가를 통한 G. oxydans의 생육 증진 효 과가 보고되었으며, 이때 사용된 glycerol 농도를 참고하여 (Kooi와 Grange, 1958) 예비실험 결과, 본 연구에서는 다당 류 제조를 위한 배양배지에 $2 \%(\mathrm{v} / \mathrm{v})$ 의 glycerol(TNT research, 
Jeonju, Korea)을 추가로 첨가해 총 7종의 배지를 제조하여 실험을 진행하였다(Table 1). G. oxydans의 배양은 $5 \mathrm{~mL}$ 의 $\mathrm{AAB}$ media가 담긴 test tube에서 전배양 $\left(30^{\circ} \mathrm{C}, 200 \mathrm{rpm}, 18\right.$ 시간)하고, $250 \mathrm{~mL}$ 의 $\mathrm{AAB}$ media에 $2 \%(\mathrm{v} / \mathrm{v})$ seed를 접종하 여 본배양 $\left(30^{\circ} \mathrm{C}, 200 \mathrm{rpm}\right)$ 하였다. 이후, 7 일 동안 진탕배양 $\left(30^{\circ} \mathrm{C}, 200 \mathrm{rpm}\right)$ 하며, 24 시간마다 배양액을 회수하여 600 $\mathrm{nm}$ 에서 흡광도를 측정함으로써 초산균의 생육곡선을 조사하 였다.

\section{DDase specific PCR primer design 및 PCR 분석}

본 연구에 사용된 G. oxydans의 DDase gene 보유 여부를 확인하기 위하여, G. oxydans ATCC 11894(accession number: LC008541)의 DDase gene 서열을 참고로 primer를 제작하였 다. DDase gene을 보유하였을 경우, 약 300-500 bp의 PCR product가 증폭되도록 specific PCR primer를 제작하였고,
DDase gene의 전체 서열 분석을 위한 primer를 제작하였다. Primer 제작에는 NCBI primer blast program(https://www. ncbi.nlm.nih.gov/tools/primer-blast)을 사용하였고, 제작된 primer 서열 및 예상 PCR product의 크기는 Table 2에 나타 내었다. G. oxydans의 genomic DNA는 genomic DNA extraction kit(Bead Genomic DNA Prep Kit For Bacterium, Cultured Cell, Biofact, Daejeon, Korea)를 이용하여 회수하 였고, 이를 주형가닥으로 사용하였다. Specific PCR 수행 조 건은 pre-denaturation $\left(94^{\circ} \mathrm{C}, 2\right.$ 분); denaturation $\left(94^{\circ} \mathrm{C}, 30\right.$ 초), annealing $\left(60^{\circ} \mathrm{C}, 1\right.$ 분), extension $\left(72^{\circ} \mathrm{C}, 2\right.$ 분), 30 cycle; final extension $\left(72^{\circ} \mathrm{C}, 5\right.$ 분 $)$; storage $\left(4^{\circ} \mathrm{C}\right)$ 이다. 증폭된 $\mathrm{DNA}$ 의 검출 을 위해 agarose(Sepro, GenDEPOT, USA)와 $1 \mathrm{X}$ TAE buffer를 사용하여 $1 \%$ gel을 만든 후 전기영동 장치(Mupid2plus, Takara, Kushikatsu, Japan)를 통해 $100 \mathrm{volt} / \mathrm{cm}$ 의 전 류로 25 분 동안 진행하여 확인하였다.

Table 1. Composition of media for dextran biotransformation by G. oxydans

\begin{tabular}{|c|c|c|c|c|}
\hline \multirow{2}{*}{ Sample abbreviation } & \multicolumn{4}{|c|}{ Composition } \\
\hline & $\begin{array}{c}\text { Acetic acid } \\
\text { bacterium media }\end{array}$ & $\begin{array}{c}\text { Glycerol } \\
(2 \%, v / v)\end{array}$ & $\begin{array}{l}\text { Maltodextrin } \\
\text { D.E. 4.0-7.0 }\end{array}$ & $\begin{array}{l}\text { Maltodextrin } \\
\text { D.E. 13.0-17.0 }\end{array}$ \\
\hline $\mathrm{G}(-) \mathrm{AAB}$ & + & - & - & - \\
\hline $\mathrm{G}(+) \mathrm{AAB}$ & + & + & - & - \\
\hline $\mathrm{G}(+) \mathrm{AAB}+1 \% \mathrm{MD} 1^{1)}$ & + & + & $1 \%(\mathrm{v} / \mathrm{v})$ & - \\
\hline $\mathrm{G}(+) \mathrm{AAB}+5 \% \mathrm{MD} 1^{1)}$ & + & + & $5 \%(\mathrm{v} / \mathrm{v})$ & - \\
\hline $\mathrm{G}(+) \mathrm{AAB}+1 \% \mathrm{MD} 2^{2)}$ & + & + & - & $1 \%(\mathrm{v} / \mathrm{v})$ \\
\hline $\mathrm{G}(+) \mathrm{AAB}+5 \% \mathrm{MD} 2^{2)}$ & + & + & - & $5 \%(\mathrm{v} / \mathrm{v})$ \\
\hline
\end{tabular}

${ }^{1)} \mathrm{MD1}$, Maltodextrin (D.E. 4.0-7.0).

${ }^{2)} \mathrm{MD} 2$, Maltodextrin (D.E. 13.0-17.0).

Table 2. Sequence of specific PCR primer for DDase

\begin{tabular}{ccc}
\hline Name & Sequence $\left(5^{\prime} \rightarrow 3\right.$ ') & PCR product (bp) \\
\hline DDase-1F & CAGAGTGCCTATCGCTCCAG & 342 \\
DDase-1R & ACGGTAAGACCCGATGAGGA & 434 \\
DDase-3F & GTTCGGGTCCTACACCCTTG & 364 \\
DDase-3R & TGGTGATGTTGGTCTGGTCG & 3,855 \\
\hline DDase-5F & TCAACCCGAACGGAACGATT & \\
DDase-5R & CAGTCGTAGGATTCACCGGG \\
\hline DDase-F:HindIII & CGACAAGCTTATGGCTGACAACTCTGACGA \\
\hline DDase-R:Xho I & GTGCTCGAGGGCGCCGACGATGTTCAT \\
\hline
\end{tabular}




\section{$\mathrm{pH}$ 및 산도 측정}

$\mathrm{pH}$ 및 산도는 초산균 배양액을 원심분리 $\left(4^{\circ} \mathrm{C}, 19,010 \times \mathrm{g}\right.$, 10 분, Himac CR21GII, Hitachi, Tokyo, Japan) 후, 배양상등 액을 회수하여 측정하였다. $\mathrm{pH}$ 는 배양상등액을 증류수로 10 배 희석 후, $\mathrm{pH}$ meter(Orion 3 star, Thermo scientific Co., Waltham, MA, USA)를 이용하여 상온에서 측정하였다. 총 산도는 시료 $1 \mathrm{~mL}$ 에 증류수 $9 \mathrm{~mL}$ 를 첨가하여 10 배 희석 후, $0.1 \%$ phenolphthalein solution을 2-3방울 가하여 붉은색이 보일 때까지 $0.1 \mathrm{~N} \mathrm{NaOH}$ 로 중화 적정하였고, 소비된 $\mathrm{NaOH}$ 의 양을 아래의 식에 대입하여 acetic acid로 환산하여 $\%$ 로 표시하였다.

$$
\text { 산도 }(\%)=\frac{\mathrm{A} \times 60(\text { acetic acid }) \times \mathrm{F}}{\mathrm{S} \times 1,000 \times 0.1} \times 100
$$
$\mathrm{A}$ : 소비된 $0.1 \mathrm{~N} \mathrm{NaOH}$ 용액의 $\mathrm{mL}$ 수
60: $0.1 \mathrm{~N} \mathrm{NaOH} 1 \mathrm{~mL}$ 에 상당하는 acetic $\operatorname{acid}(\mathrm{g})$
F: $0.1 \mathrm{~N} \mathrm{NaOH}$ 용액의 역가
$\mathrm{S}$ : 적정에 사용된 배양 상등액의 양 $(\mathrm{mL})$
$0.1: \mathrm{NaOH}$ 의 농도

\section{환원당 함량 측정}

환원당은 glucose oxidase/peroxidase 또는 hexokinase/ G6P-DH 효소 작용을 기반으로 분석 가능한 GOPOD kit (D-glucose assay kit, Megazyme, Bray, Co. Wicklow, Ireland)를 이용하여 각 배지별 G. oxydans 배양상등액의 환 원당 함량을 측정하였다(www.megazyme.com). D-glucose 포 함된 배양상등액 $1 \mathrm{~mL}$ 에 $\mathrm{GOPOD}$ reagent $3 \mathrm{~mL}$ 를 혼합하여 $40^{\circ} \mathrm{C}$ 에서 20 분간 반응시킨 후, microplate reader(Multiskan Sky, Thermo Scientific Co.)를 이용하여 OD510 nm에서 흡 광도를 측정하였다. 측정된 흡광도 값을 아래의 식에 대입하 여 환원당의 함량을 계산하였다.

$\mathrm{D}-\operatorname{glucose}(\mu \mathrm{g} / 0.1 \mathrm{~mL})=$

$$
\frac{\Delta \mathrm{A}_{\text {sample }}}{\Delta \mathrm{A}_{\mathrm{D}-\text { glucosestandard(100 } \mu \mathrm{g})}} \times 100
$$

\section{점도 측정}

배지의 구성(첨가된 기질의 중합도 및 농도)에 따른 초산 균의 다당류 생성 유무를 확인하기 위하여 배양액을 원심분 리(19,010 $\times g, 10$ 분)한 후, 배양상등액의 유변학적 특성을 분 석하였다. 유동 특성은 rherometer(MCR 302, Anton Paar Co., Graz, Austria)를 사용하여 측정하였으며, probe는
PP-50, 온도는 $25^{\circ} \mathrm{C}$, shear rate는 $0.01-300$ 의 범위 내에서 총 30 번 측정하였다(Im 등, 2015).

\section{High performance anion exchange chromatography (HPAEC)}

초산균 배양 시 배지의 구성(첨가된 기질의 중합도 및 농 도)에 따라 생성되는 다당류의 차이를 확인하기 위하여, 배양 상등액을 이용해 $\mathrm{HPAEC}$ 를 수행하였다. 배양상등액을 증류 수로 5 배 희석하여 $0.22 \mu \mathrm{m}$ syringe filter $(13 \mathrm{~mm}, 0.22 \mu \mathrm{m}$, NYLON, Thermo Fisher Scientific Co.)로 여과하여 분석시 료로 사용하였다. 각 배양상등액이 함유하고 있는 구성 당류 의 패턴 분석을 위해 Jeong 등(2019)의 연구에서 적용한 방 법을 참고하였다. ICS 5000 Dionex chromatography system (ICS-5000+ Capillary HPIC ${ }^{\mathrm{TM}}$ System, Thermo Fisher Scientific Co. $)$ 에 CarboPac PA200 column $(3 \times 250 \mathrm{~mm}$, Dionex $)$ 를 장 착하여 분석하였고, 분석시스템은 $\mathrm{PEEK}$ tube $(0.24 \mathrm{~mm}$ i.d. $)$, a gradient mixer $(2 \mathrm{~mm}), \mathrm{ED}$ amperometry cell with $0.25 \mu \mathrm{L}$ channel volume, a $\mathrm{pH}-\mathrm{Ag} / \mathrm{AgCl}$ reference electrode, 0.002 in gasket, and gold electrodes을 포함하였다. 분석조건으로 분 석용매는 $100 \mathrm{mM}$ sodium hydroxide와 $1 \mathrm{M}$ sodium acetate 를 사용하였고, sodium acetate는 15-50분 동안 0-400 mM까 지 농도구배를 주어 분석하였으며, column의 온도는 $40^{\circ} \mathrm{C}$, 샘플 주입량은 $5 \mu \mathrm{L}$, 용매 유속은 $0.5 \mathrm{~mL} / \mathrm{min}$ 의 조건으로 분 석하였다.

\section{${ }^{1} \mathrm{H}-\mathrm{NMR}$ (proton nuclear magnetic resonance) 분석}

배지의 구성(첨가된 기질의 중합도 및 농도)에 따라 생성 된 다당류의 당 분자 간 $\alpha-1,4$ 및 $\alpha-1,6$ 결합의 함량 분석을 위하여, 배양상등액을 이용해 ${ }^{1} \mathrm{H}-\mathrm{NMR}$ spectroscopy $(500$ $\mathrm{MHz}$ FT-NMR, JEOL, Tokoy, Japan)를 수행하였다. 동결 건 조된 sample $(20 \mathrm{mg} / \mathrm{mL})$ 을 산화중수소 $\left(\mathrm{D}_{2} \mathrm{O}\right)$ 에 녹여준 뒤 4 $0^{\circ} \mathrm{C}$ 에서 10 분간 반응시킨 후 다시 동결건조하였다. 동결건 조된 시료를 $20 \mathrm{mg} / \mathrm{mL}$ 의 농도가 되도록 산화중수소에 다시 용해한 후, ${ }^{1} \mathrm{H}-\mathrm{NMR}$ 분석을 수행하였다.

\section{통계처리}

본 실험은 모두 3 회 이상 반복 측정한 결과값을 SPSS 24.0(Statistical Package for Social Science. SPSS Inc., Chicago, IL, USA) 프로그램의 기술통계를 통해 '평균 \pm 표준 편차’의 형태로 나타내었고, 일원배치 분산분석(Oneway analysis of variance)을 통해 유의성 검증을 하였으며, Duncan 의 다중범위검정(Duncan's multiple range test)을 통해 시료 간의 유의차를 검정하였다 $(\mathrm{p}<0.05)$. 


\section{결과 및 고찰}

\section{DDase gene의 specific PCR}

G. oxydans 균주 내 당전이 활성이 있는 효소, dextrandextrinase(DDase) gene 보유 여부를 확인하기 위하여, NCBI 에서 G. oxydans ATCC 11894의 DDase gene sequence를 참 고로 제작한 specific PCR pirmer를 이용하여 PCR을 수행하 였다. G. oxydans의 genomic DNA를 주형가닥으로 PCR 실 시 후 DNA 전기영동 결과, 예상 크기인 $342,434,364$ bp에 서 PCR product가 검출되었으므로(Fig. 1A), 실험에 사용된 G. oxydans 균주의 염색체 내 DDase gene을 포함하고 있을 것으로 추정되었다. DDase gene의 domain 분석 결과, $G$. oxydans의 DDase gene 보유 여부를 확인하기 위해 제작된 primer set 5의 경우 DDase gene을 구성하고 있는 COG2931 family sequence 내에 위치함으로 DDase specific PCR primer로 사용이 가능함을 확인하였다(Fig. 1B).

G. oxydans ATCC 11894 서열을 참고하여 $3.4 \mathrm{~kb}$ 상당의 DDase gene 증폭용 primer(Table 2)를 제작하여 PCR을 수 행하였고, PCR product의 서열을 분석하여 분양받은 $G$. oxydans 유래의 DDase gene 서열을 확보하였다(data not shown). DDase gene의 서열 분석을 통해 기존에 보고된 $G$. oxydans ATCC 11894의 DDase gene 서열과 99\% 상동성
(3,848/3,855 nucleotides)이 확인되었다. 서열분석된 DDase gene(PCR product)을 NCBI의 blastX 프로그램을 이용하여 데이터베이스 상에 등록된 아미노산 서열과 비교분석한 결과, Gluconobacter sp. LMG 31484, Gluconobacter cerevisiae, Acetobater malorum, Gluconaetobacter sacchari, Nguyenibacter vanlangensis의 hypothetical protein과 $99 \%$ 상동성을 확인 하였으며, DDase gene은 CBM6-CBM5, GH(glycoside hydrolase) family 15 및 COG2931 family의 3 개 domain으로 구성되어 있음을 확인하였다. 따라서 본 연구를 위해 분양받 은 G. oxydans는 DDase gene을 함유하고 있으므로 다당류를 제조하기 위해 적합한 균주로 예상된다.

\section{생육곡선}

G. oxydans의 배양을 통해 dextrin을 dextran으로 생물전 환하기 위하여, 초산균 배양에 적합한 배지조건을 탐색하고 자 하였다. 일반적으로 초산균 배양 시, acetic acid 등의 대사 산물의 생성으로 인해 배지의 산성화가 발생하며, 이에 따른 catabolite repression에 의해 장시간 배양이 어려운 것으로 알려 져 있다(Brueckner와 Titgemeyer, 2002). Naessens 등(2005b)및 Kooi와 Grange(1958)에 따르면 배지 내 glycerol, sorbitol 등 다가알코올 첨가가 완충작용을 통해 초산균의 생육을 증진시 킨다고 보고하였다. $2 \%(\mathrm{v} / \mathrm{v})$ glycerol 첨가군과 무첨가군 배양

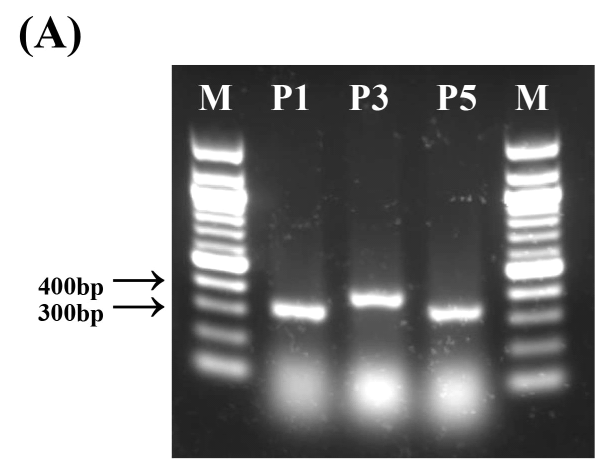

(B)

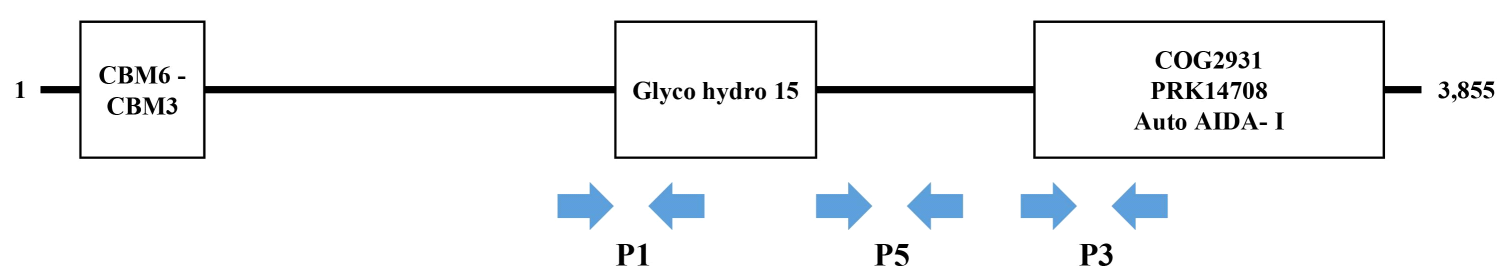

Fig. 1. G. oxydans specific PCR (A) and DDase gene structure (B).

A, electrophoresis results of DNA amplified by DDase gene, PCR product of expected size detected; B, DDase gene domain analysis results, the primer sets 'P1', 'P5' and 'P3' are located in the sequence constituting the DDase gene, it can be used as a DDase-specific PCR primer. 
배지를 제조하여 glycerol 첨가로 인한 생육 증진 확인 및 dextran 전환의 기질로 사용되는 dextrin의 중합도(MD1, MD2) 및 첨가 수준별 $(1 \%, 5 \%)$ 생육곡선을 확인하였다. 각 배양배 지의 조건에서 배양 7일차까지 G. oxydans의 생육을 비교한 결과, 배양 1 일차에는 모든 시험구 간에 유의적인 차이를 확 인할 수 없었다. Glycerol 무첨가구()의 경우 배양 5 일차에 $0.44 \pm 0.01$, 배양 7 일차에 $0.35 \pm 0.00$, glycerol 첨가구 $(\bigcirc)$ 의 경우 배양 5 일차에 $0.80 \pm 0.00$, 배양 7 일차에 $0.88 \pm 0.02$ 의 흡 광도를 보였으므로, glycerol의 첨가가 G. oxydans의 생육을 증가시키는 것을 확인하였다(Fig. 2). 또한 glycerol 첨가군 간에는 배양 2 일차까지 시료 간의 유의적인 차이가 없었으 나, 배양 3 일차부터 유의적인 차이가 발생하였다. 배양 3 일차 에 $\mathrm{G}(+) \mathrm{AAB}+5 \% \mathrm{MD} 2(\square)$ 가 다른 glycerol 첨가구에 비하여 낮은 생육도를 보였으며, 배양 4일차부터 maltodextrin 무첨가 구인 $\mathrm{G}(+) \mathrm{AAB}(\mathrm{O})$ 의 생육이 maltodextrin 첨가군 $(\nabla, \triangle, \boldsymbol{\square}$, $\square)$ 에 비하여 유의적으로 낮은 생육이 확인되었다 $(\mathrm{p}<0.05)$. 따라서 maltodextrin의 첨가가 G. oxydans의 생육에 영향을 미치는 것을 확인할 수 있었다. 이는 G. oxydnas를 $60 \mathrm{~L}$ scale 로 배양하며, 탄소원 및 질소원을 조사한 연구(Naessens 등, 2004; Naessens 등, 2005b)에서 보고한 결과와 유사한 경향 을 나타냄으로써 DDase 당전이 활성이 있는 초산균 배양 시 maltodextrin 첨가는 생육 증진에 유효한 효과를 보이는 것을 확인하였다.

\section{$\mathrm{pH}$ 및 산도}

G. oxydans 배양을 통한 효율적 dextran 생물전환을 위한 배지탐색을 위해 G. oxydans의 배지조건 및 배양기간에 따른

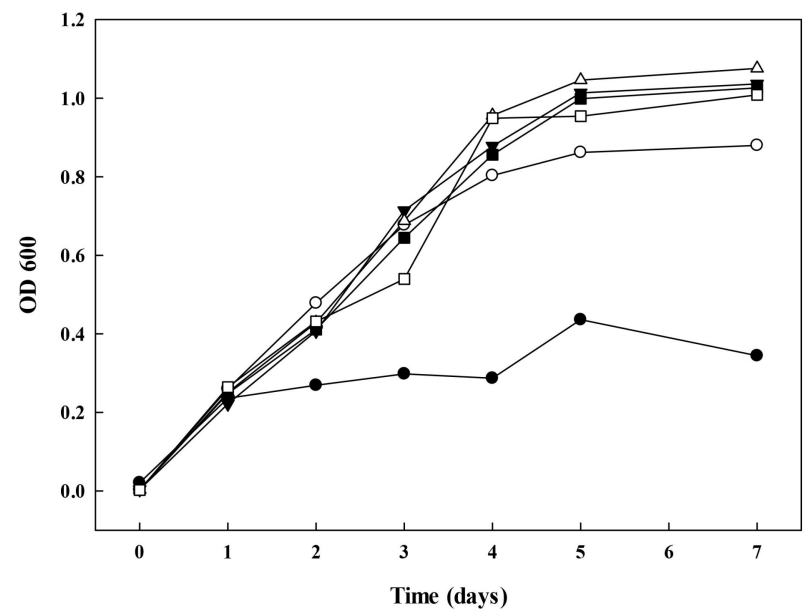

Fig. 2. Growth curve of G. oxydans according to various media type.

๑, G(-)AAB; $\bigcirc, \mathrm{G}(+) \mathrm{AAB} ; \boldsymbol{\nabla}, \mathrm{G}(+) \mathrm{AAB}+1 \% \mathrm{MD} 1 ; \triangle, \mathrm{G}(+) \mathrm{AAB}+$ $5 \% \mathrm{MD} 1 ; \square, \mathrm{E} \mathrm{G}(+) \mathrm{AAB}+1 \% \mathrm{MD} 2 ; \square, \mathrm{G}(+) \mathrm{AAB}+5 \% \mathrm{MD} 2$.
$\mathrm{pH}$, 산도의 변화를 조사하여 그림에 나타내었다(Fig. 3). 모 든 시험구에서 초기 산도는 $\mathrm{pH}$ 5.7-5.9로 유의적인 차이가 없었으며, 배양 1 일차에 $\mathrm{pH}$ 가 급격히 감소하여 $\mathrm{pH}$ 3.5-3.7을 나타내었다. 이후에는 배양 7 일까지 $\mathrm{pH}$ 가 점차 감소하는 경 향을 보였으며, 배양기간이 증가할수록 시료 간의 유의적인 차이를 보임을 확인하였다 $(\mathrm{p}<0.05)$. 이는 초산균의 배양 시, 배양 대사산물로 acetic acid가 생성되어 배양 1 일차에 $\mathrm{pH}$ 가 급격히 낮아진 것으로 예상되며, 발효 초기 $\mathrm{pH}$ 가 낮을 경우, 초산균의 유도기가 증가되어 발효가 제대로 일어나지 않기 때문에 $\mathrm{pH}$ 의 감소가 적다고 보고되어진 $\mathrm{Kim}$ 등(1985)의 연 구와 초기 $\mathrm{pH}$ 가 6.0-6.5인 환경에서 초산균의 생육도가 우수 하다고 보고한 $\mathrm{Kim}$ 등(2012)의 연구와 같이 배양 1 일 이후 에 $\mathrm{pH}$ 가 약 3.5-3.7로 낮은 $\mathrm{pH}$ 의 배양조건이 형성되었으므 로 G. oxydans의 생육도가 낮은 것은 이와 연관이 있을 것으 로 사료된다. 산도는 중합도가 다른 당(MD1, MD2)을 2가지 농도 $(1 \%, 5 \%)$ 로 첨가하였을 경우, 모든 시험구에서 배양 0 일차에는 $0.10-0.12 \%$ 로 유의적인 차이가 없었으나, 배양 1 일 차에 급격히 증가하였고, 이후 배양기간 동안 계속하여 증가하 는 경향을 보였다. 배양 7일차에는 당 무첨가구인 $\mathrm{G}(+) \mathrm{AAB}$ (O)는 $0.40 \pm 0.01 \%$ 로 나타났으며, 당 첨가구인 $\mathrm{G}(+) \mathrm{AAB}+$ $1 \% \mathrm{MD} 1(\boldsymbol{\nabla})$ 은 $0.41 \pm 0.01 \%, \mathrm{G}(+) \mathrm{AAB}+5 \% \mathrm{MD} 1(\triangle)$ 은 $0.51 \pm$ $0.01 \%, \mathrm{G}(+) \mathrm{AAB}+1 \% \mathrm{MD} 2(\boldsymbol{\square})$ 는 $0.46 \pm 0.01 \%, \mathrm{G}(+) \mathrm{AAB}+$ $5 \% \mathrm{MD} 2(\square) 0.68 \pm 0.01 \%$ 로 나타나, $\mathrm{MD} 1$ 에 비하여 $\mathrm{MD} 2$ 를 첨가한 시험구에서 다소 높은 산도가 확인되었으며, 당 무첨 가구(O)에 비해 $1.05,1.28,1.15,1.71$ 배 높은 산도가 확인되 었다. 그리고 배양기간이 증가하고, 당의 함량이 높아질수록 산도가 더 큰 폭으로 증가하는 경향을 확인하였다.

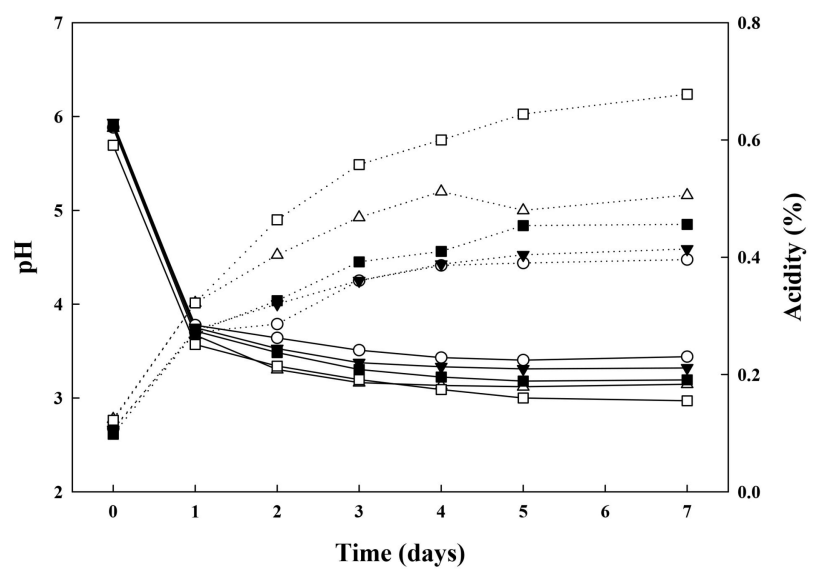

Fig. 3. Changes in pH (solid line) and acidity (short dash line) of the culture supernatant of $G$. oxydans according to various media types.

$\mathrm{O}, \mathrm{G}(+) \mathrm{AAB} ; \boldsymbol{\nabla}, \mathrm{G}(+) \mathrm{AAB}+1 \% \mathrm{MD} 1 ; \triangle, \mathrm{G}(+) \mathrm{AAB}+5 \% \mathrm{MD} 1$ $\mathrm{G}(+) \mathrm{AAB}+1 \% \mathrm{MD} 2 ; \square, \mathrm{G}(+) \mathrm{AAB}+5 \% \mathrm{MD} 2$. 


\section{환원당}

당전이 활성이 있는 초산균인 G. oxydans의 배양조건별 다당류 제조능을 확인하기 위하여 glycerol 첨가군의 배양기 간에 따른 환원당의 당량 변화를 조사하였다(Fig. 4). 환원당 은 반응성이 있는 알데히드기나 케톤기를 갖고 금속염 알칼 리 용액을 환원시키는 성질을 갖는 당을 말하며(Lee 등, 2018), glycerol 첨가군의 배양 0 일차 환원당의 함량은 $1.94-1.98 \mu \mathrm{g} / 0.1 \mathrm{~mL}$ 로 시험구 간의 유의적인 차이가 없었으 나, 배양 1 일차에는 $\mathrm{G}(+) \mathrm{AAB}(\mathbf{\bullet}), \mathrm{G}(+) \mathrm{AAB}+1 \% \mathrm{MD} 1(\boldsymbol{\nabla})$, $\mathrm{G}(+) \mathrm{AAB}+5 \% \mathrm{MD} 1(\triangle), \mathrm{G}(+) \mathrm{AAB}+1 \% \mathrm{MD} 2(\boldsymbol{\square}), \mathrm{G}(+) \mathrm{AAB}+$ $5 \% \mathrm{MD} 2(\square)$ 의 순으로 $0.03 \pm 0.00, \quad 0.08 \pm 0.00, \quad 0.14 \pm 0.00$, $0.41 \pm 0.00,0.51 \pm 0.00 \mu \mathrm{g} / 0.1 \mathrm{~mL}$ 으로 환원당의 함량이 급격 히 감소하였다. 이는 $\operatorname{Kim}$ 등(1993)에 의하면 미생물 생육 시 환원당을 기질로 사용함으로써 배지 내 환원당의 함량이 감소 한다는 보고한 바와 같이, 배양 초기 다당류 생산을 위해 첨가 한 maltodextrin을 G. oxydans가 생육을 위해 이용함으로써 배양 1 일차에 환원당의 함량이 급속히 감소한 경향을 나타내 는 것으로 보인다. $\mathrm{G}(+) \mathrm{AAB}+5 \% \mathrm{MD} 2(\square)$ 배지의 경우, 다른 시험구에 비하여 배양 3 일차에 다소 낮은 생육을 나타내다가 배양 4 일차에 다시 증가하는 것을 확인한 반면, 환원당 함량은 생육이 증가하는 배양 4일차에 감소하였으므로, G. oxydans가 maltodextrin을 기질로 사용하여 생육함으로써 환원당의 함 량이 감소한 것으로 예상된다. 그리고 dextran dextrinase 작 용을 통해 dextran 전환 시, 환원성 말단의 glucose 잔기를 가수분해하여 당전이 생성물을 형성하므로 중합도가 낮은 $\mathrm{MD} 2$ 의 환원당 함량이 높은 경향을 보이는 것으로 예상된다. 또한, dextran으로부터 isomaltooligosaccharide 제조를 위한

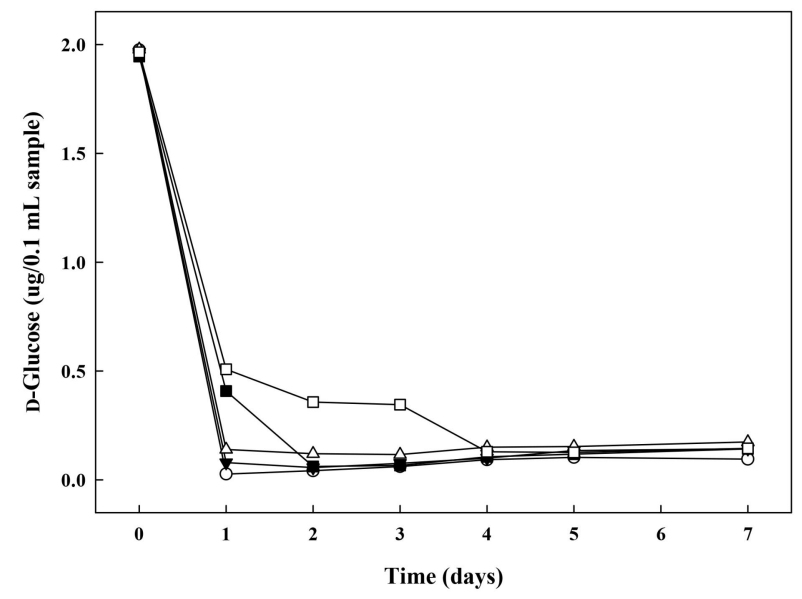

Fig. 4. Changes in reducing sugar content of the culture supernatant of $\boldsymbol{G}$. oxydans according to various media types.

$\mathrm{O}, \mathrm{G}(+) \mathrm{AAB} ; \boldsymbol{\nabla}, \mathrm{G}(+) \mathrm{AAB}+1 \% \mathrm{MD} 1 ; \triangle, \mathrm{G}(+) \mathrm{AAB}+5 \% \mathrm{MD} 1 ; \mathbf{\square}, \mathrm{E}$ $\mathrm{G}(+) \mathrm{AAB}+1 \% \mathrm{MD} 2 ; \square, \mathrm{G}(+) \mathrm{AAB}+5 \% \mathrm{MD} 2$. dextranase 고정화 연구(Bertrand 등, 2014)에서는 dextran의 가수분해로 인해 생성된 환원당 증가를 통해 시간에 따른 효 소반응 생성물 증가를 설명하는 등 환원당 함량변화는 가수 분해 및 당전이 효소 반응물의 생성 여부를 판단하는 척도가 될 수 있음을 알 수 있다.

\section{점도}

배지 구성별 당전이 활성 균주의 배양 전 후 점도의 변화 를 측정하기 위하여 배양 전 배지 및 7일 배양 후 배지의 점 도를 조사하였다. G. oxydans 균주 접종 전 모든 배지의 점도 는 전단속도가 증가할수록 전단응력이 비례하여 증가하는 경 향을 보여 newtonian 성질의 유체임을 확인하였다(Fig. 5A). 그러나 7일간 배양 후 회수한 배양 상등액의 경우, shear rate 증가에 따른 전단응력(shear stress)이 감소하는 pseudoplastic 한 성질의 유체 특성을 보였다. 이는 다당류 생성 증가로 인 한 shear-thinning한 성질이 강화됨으로써 유동 특성이 변한 것으로 판단되었다.

특히 초산균의 당전이 효소의 기질로 사용되는 dextrin의 중합도 및 첨가수준별 배양 상등액의 차이로는, dextrin $1 \%$ 첨가군 $(\mathrm{G}(+) \mathrm{AAB}+1 \% \mathrm{MD} 1, \mathrm{G}(+) \mathrm{AAB}+1 \% \mathrm{MD} 2)$ 대비 $5 \%$ 첨 가군 배지 배양액 $(\mathrm{G}(+) \mathrm{AAB}+5 \% \mathrm{MD} 1, \mathbf{\nabla} ; \mathrm{G}(+) \mathrm{AAB}+5 \% \mathrm{MD} 2$ 口)에서 전단율이 증가할수록 증단응력의 증가율이 감소하는 특성이 강하게 나타나, dextrin의 첨가수준이 높은 처리구 내 고분자 다당류 생성량이 높을 것으로 추정하였다.

고분자 다당류인 dextran과의 전단응력을 비교하기 위하 여 $20 \%$ dextran 수용액의 점도 특성을 비교하였다(Fig. 5C). G. oxydans를 $\mathrm{G}(+) \mathrm{AAB}+5 \% \mathrm{MD} 1$ 에 접종 - 배양하여 회수한 배양상등액의 경우, 다당류 생성으로 인하여 $20 \%$ dextran의 겉보기 점도(apparent viscosity)인 $5.87 \pm 0.19 \mathrm{mPa} \cdot \mathrm{s}$ 와 유 사한 값인 $5.53 \pm 0.05 \mathrm{mPa} \cdot \mathrm{s}$ 로 확인되었다(Table 3). 기질의 중합도 차이에 대하여는 maltodextrin의 중합도가 낮은 $\mathrm{G}(+) \mathrm{AAB}+5 \% \mathrm{MD} 2$ 처리구 대비 $\mathrm{G}(+) \mathrm{AAB}+5 \% \mathrm{MD} 1$ 배양 상등액의 전단응력의 변화가 더 두드러졌음을 확인하였다 (Fig. 5B). 이러한 기울기의 변화는 전단속도의 증가에 따른 응집구조의 파괴로 인한 shear thining 현상으로 보고(Tako 등, 1977)되고 있으며, Lee 등(1996)은 고분자 수용액은 입자 간의 2 차 결합력 등 구조형성능력으로 인해 항복응력 값과 밀접한 관련이 있고, 고분자 용액의 농도가 증가할수록 분자 간의 엉킴 밀도가 증가하여 엉킴의 정도에 의해 외부에서 가 해지는 힘에 대한 반응이 다르게 나타나는 현상이라고 보고하 였다. Vuillemin 등(2018)의 연구에서는 O. kitaharae DSM 17330 유래 dextransucrase 활성으로 생성된 dextran의 점도 를 확인한 결과, 산업적으로 활용되는 L. mesenteroides NRRL 유래 dextran보다 더 높은 점도와 독특한 유변학적 특 


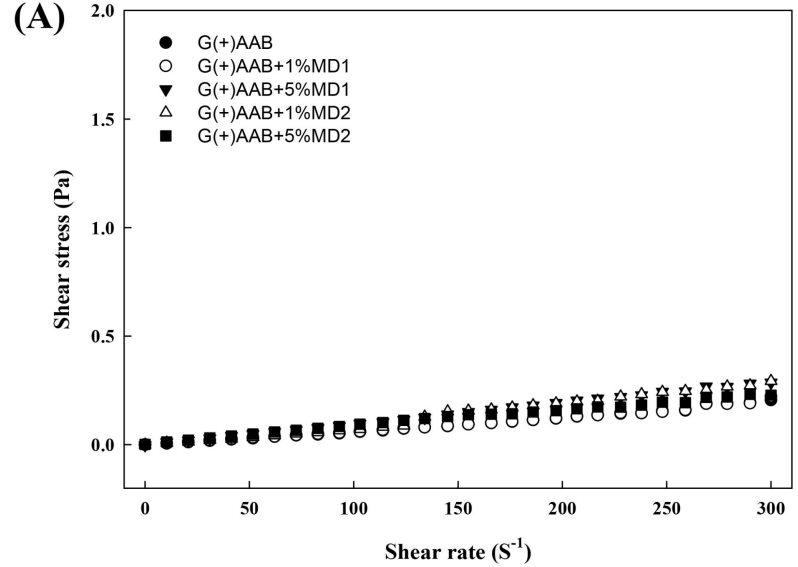

(B)

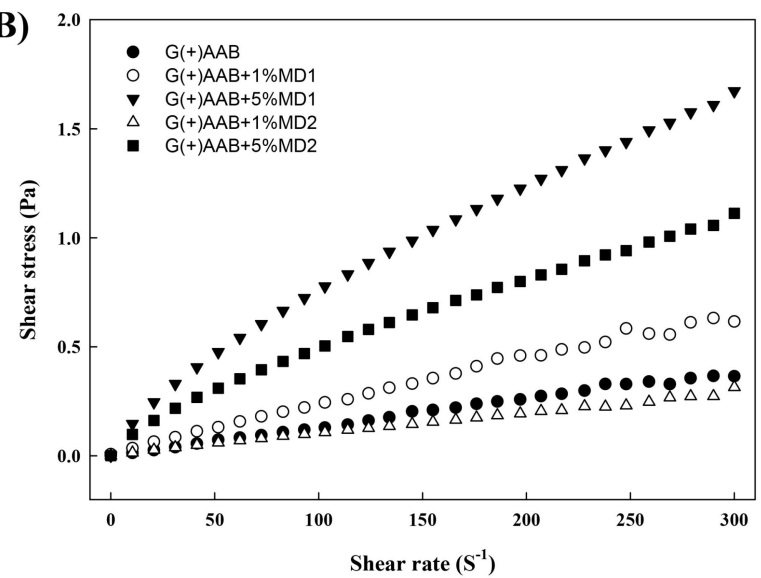

(C)

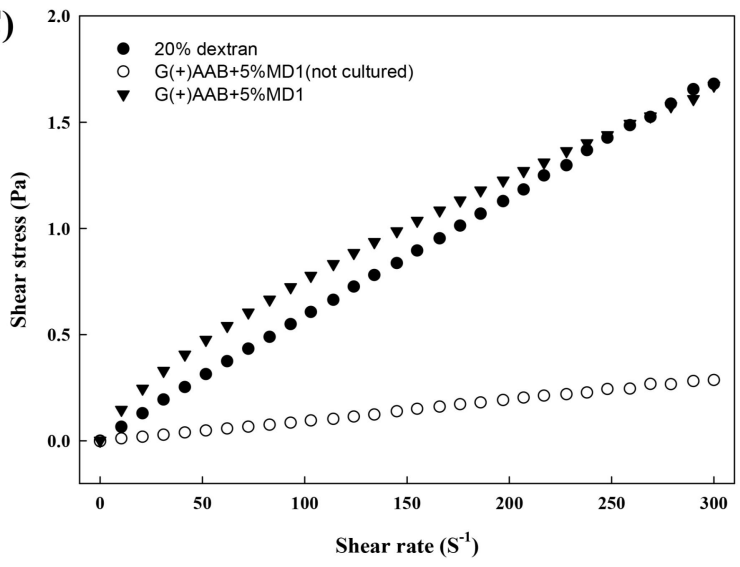

Fig. 5. Shear stress-shear rate plots of G. oxydans in variable culture supernatants.

A, media for not cultivation; B, media cultured for 7 days; C, comparison with $20 \%$ dextran (positive control), media for not cultivation and media cultured for 7 days. Significant differences were compared with A and B. Production of polysaccharides was confirmed in the culture media.

성을 보인다고 하였다. 이는 다양한 균주 유래의 효소는 서로 다른 효소 활성을 보여 다양한 생성물을 합성하기 때문이며
Table 3. Rheological properties of culture media

\begin{tabular}{cc}
\hline Sample $^{1)}$ & $\begin{array}{c}\text { Apparent viscosity } \\
(\mathrm{mPa} \cdot \mathrm{s})\end{array}$ \\
\hline $20 \%$ dextran solution & $5.87 \pm 0.19$ \\
$\mathrm{G}(+) \mathrm{AAB}+1 \% \mathrm{MD} 1$ & $1.80 \pm 0.22$ \\
$\mathrm{G}(+) \mathrm{AAB}+5 \% \mathrm{MD} 1$ & $5.53 \pm 0.05$ \\
$\mathrm{G}(+) \mathrm{AAB}+1 \% \mathrm{MD} 2$ & $1.03 \pm 0.05$ \\
$\mathrm{G}(+) \mathrm{AAB}+5 \% \mathrm{MD} 2$ & $3.67 \pm 0.12$ \\
\hline
\end{tabular}

${ }^{1)}$ Abbreviations: See the Table 1 except dextran

${ }^{2)}$ All values are mean \pm SD $(n=3)$.

(Pazur와 Ando, 1961), 따라서 분리된 균주별 생성물의 특성 차이를 파악하기 위한 기초 연구들이 더욱 활발히 수행되어 야 할 것으로 사료된다.

\section{$\mathrm{HPAEC}$ 에 의한 생성물 분석}

당전이 활성이 있는 초산균의 배양 조건에 따른 배지 내 구성당 변화 및 생성물의 구성당 패턴을 확인하기 위하여, 배 양일별로 sampling하여 배양액 내 첨가한 기질의 감소 및 다 당류 생성을 관찰하였다. dextrin 첨가 배지 내 구성은 포도당 $(\mathrm{G} 1)$, 말토오스 $(\mathrm{G} 2)$ 및 말토트리오스 $(\mathrm{G} 3)$ 등 말토올리고당 류로 구성되어 중합도 11 이상의 당류를 포함하고(Fig. 6A), dextran $1 \%$ 수용액은 분석시간 20 분 이후에 나타난 peak를 통 해 고중합도의 다당류로 구성됨을 비교하였다(Fig. 6B). 배양회 수액에서 dextrin $1 \%$ 첨가군 $(\mathrm{G}(+) \mathrm{AAB}+1 \% \mathrm{MD} 1, \mathrm{G}(+) \mathrm{AAB}+$ $1 \% \mathrm{MD} 2)$ 은 배양 1 일차, $5 \%$ 첨가군 $(\mathrm{G}(+) \mathrm{AAB}+5 \% \mathrm{MD} 1$, $\mathrm{G}(+) \mathrm{AAB}+5 \% \mathrm{MD} 2)$ 은 배양 2 일차에 대부분의 dextrin peak 가 사라졌으며(data not shown), 이를 통해 G. oxydans 균주 가 생육 및 dextran 생물전환을 위해 dextrin을 활발히 소비하 는 것을 알 수 있었다. 7일간 G. oxydans ATCC 배양회수액 내 다당류 전환을 확인하기 위해 에탄올 침전 회수된 시료의 구성당 변화 결과, dextrin 무첨가 배지 $(\mathrm{G}(+) \mathrm{AAB})$ 와는 달리 $5 \%$ dextrin 첨가 배지 $(\mathrm{G}(+) \mathrm{AAB}+5 \% \mathrm{MD} 1, \mathrm{G}(+) \mathrm{AAB}+5 \% \mathrm{MD} 2)$ 에서 회수된 물질의 구성당 패턴은 20 분 이후 dextran의 구성 당 패턴과 유사한 것으로 나타났으며, 주로 20-30분 사이에 peak를 형성하는 pattern을 보였다. 또한 중합도가 높은 dextrin 배지, $\mathrm{G}(+) \mathrm{AAB}+5 \% \mathrm{MD} 1$ 대비 중합도가 낮은 dextrin 배지 $(\mathrm{G}(+) \mathrm{AAB}+5 \% \mathrm{MD} 1)$ 에서 peak를 나타내는 물질의 함량이 높게 나타났다(Fig. 6D, E). Yamamoto(1992)는 Acetobacter capsulatus ATCC11894 유래 DDase가 다양한 기질에 의한 dextran 형성능을 조사한 결과, Glucose $\mathrm{G} 2$ 를 제외한 모든 기질로부터 dextran을 합성할 수 있었고, 평균중합도(DP) 17.3에 해당하는 short chain amylose 이용 시 dextran 수율이 
(A)

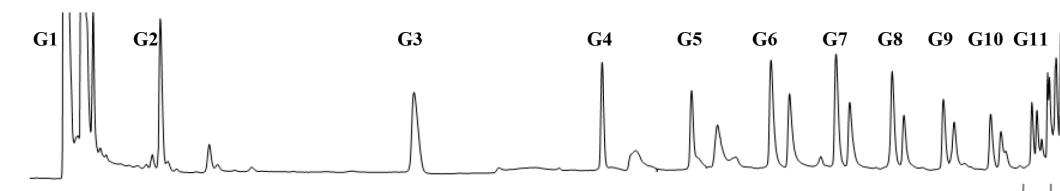

(B)

(C)

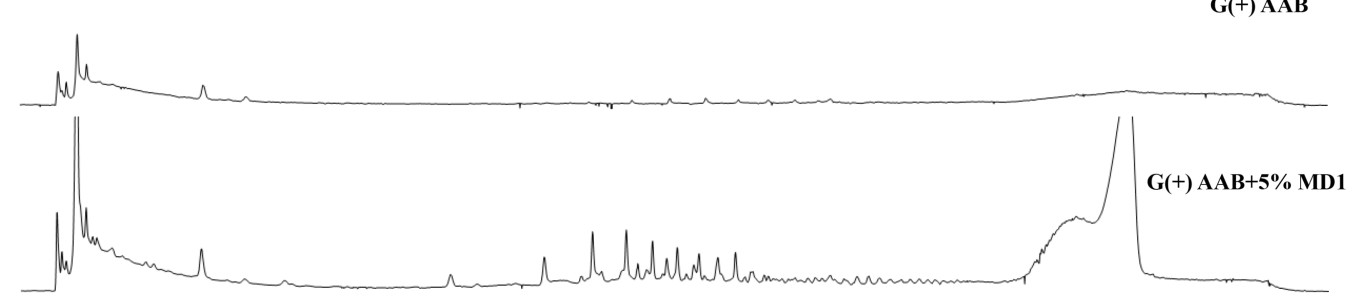

(E)

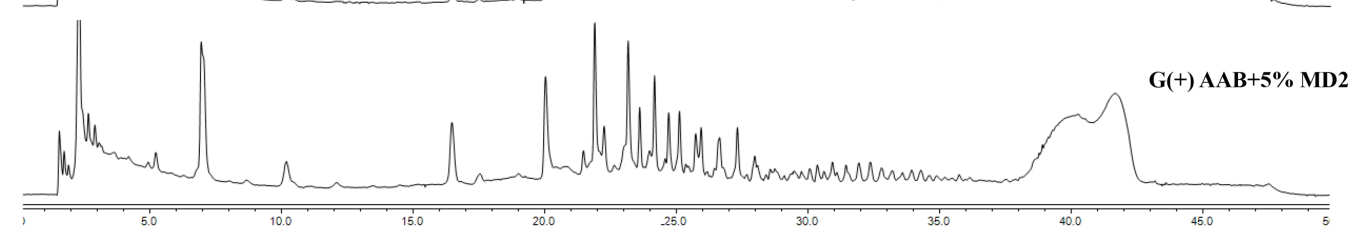

Fig. 6. Polysaccharide composition analysis by HPAEC-PAD.

A, G. oxydans culture media $\mathrm{G}(+) \mathrm{AAB}+5 \% \mathrm{MD} 1$; B, dextran (positive control); C-E, analysis of ethanol precipitation products in culture.

$57.6 \%$ 로 가장 높은 것으로 보고하였다. 반면 soluble starch 는 $21.4 \%$ 로 보고되어 사전연구와 유사한 경향을 나타내었다. Nacssens와 Vandamme(2001)에 따르면, intracellular DDase 는 maltose(G2)와 반응하여 폴리머의 형성 없이 glucose와 panose만 생성하였고, Sadahiro 등(2015)의 연구에서 또한, 기질로 첨가한 maltotetraose $(\mathrm{G} 4)$ 로부터 $\mathrm{G} 3, \mathrm{G} 5$ 외에 panose 가 분석된 것으로 보고하였는데, 본 연구의 배양상등액 회수 물의 분석 결과 panose peak가 일부 관찰된 것과 일치하며 (Fig. 6E), 이는 당전이 효소작용에 의해 $\alpha-1,6$ glycosidic linkage를 포함한 물질의 형성을 의미한다. 추후 배양상등액 에서 회수된 물질의 다당류 결합 패턴을 확인하기 위해 ${ }^{1} \mathrm{H}-\mathrm{NMR}$ 분석을 실시하였다.

\section{${ }^{1} \mathrm{H}-\mathrm{NMR}$ 에 의한 다당류의 구조 분석}

G. oxydans ATCC 19357에서 회수한 다당류의 구조 분석 을 위하여 ${ }^{1} \mathrm{H}-\mathrm{NMR}$ 을 실시하였다. Dextran의 구조 분석은 여 러 가지 방법으로 연구할 수 있으나, 그중 NMR spectroscopy 는 1D 및 2D NMR spectra(TOCSY, NOESY, ROESY, $\mathrm{HSQC}$ 및 $\mathrm{HMBC})$ 의 적용을 통해 dextran의 자세한 구조정 보를 얻기 위한 가장 중요한 기술이다(Purama 등, 2009; Wang 등, 2007). 앞서 HPAEC- PAD 분석을 통해 확인한 dextrin 첨가 7일 배양회수액에 함유된 다당류의 분자간 결합 을 확인하기 위해 ${ }^{1} \mathrm{H}-\mathrm{NMR}$ 분석결과를 나타내었다(Fig. 7). G. oxydans의 기질로 사용되는 dextrin의 분자 간 결합 분석 결과, chemical shift 값은 $5.3 \mathrm{ppm}$ peak를 보여 $\alpha-1,4$ glycosidic linkage 물질이 가지는 특징을 확인하였고, positive control로 사용한 dextran에서 확인된 $4.92 \mathrm{ppm}$ 의 anomeric proton signal은 전형적인 $\alpha-1,6$ glycosidic linkage를 포함하 는 물질임을 확인하였다(Tizzotti 등, 2011). G(+)AAB+ $5 \% \mathrm{MD} 2$ 배양 상등액에서 회수한 다당류의 chemical shift peak 형태는 $4.92 \mathrm{ppm}$ 위치에서 major peak, $5.3 \mathrm{ppm}$ 위치 에서 minor peak가 관찰되어, G. oxydans 유래 DDase의 당 전이 반응을 통해 maltodextrin을 기질로 이용하여 $\alpha-1,6$ glycosidic linkage 포함한 물질인 dextran으로 전환된 것으로 판단되었다(Fig. 7C).

Hehre(1951)에 의하면 DDase는 dextrin의 비환원성 말단 의 $\alpha-1,4$ glucosyl 잔기 또한 dextran 전환하는 작용이 가능하 다고 제안된 것과 같이, dextrin의 $\alpha-1,4$ glucosyl 잔기로 인해 chemical shift 4.92 위치에 peak를 확인할 수 있었으며, 첨가 된 maltodextrin이 전량 dextran으로 생물전환에 이용되지 못 하고 남아 있는 잔여 기질에 의한 영향으로도 판단된다. 따라 서 당전이 활성 초산균의 배양기간 연장 및 비연속식 기질 주 


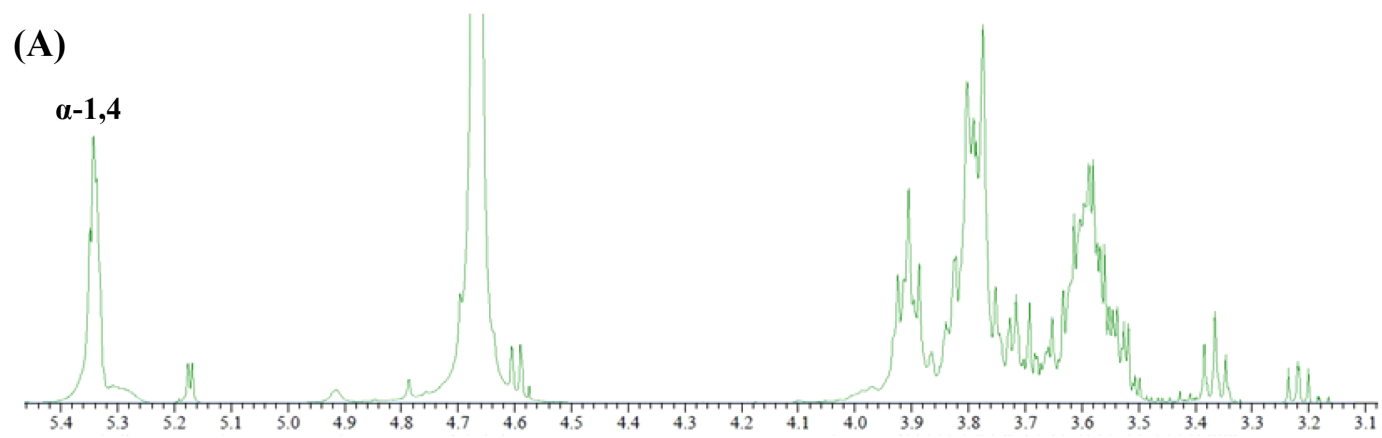

(B)

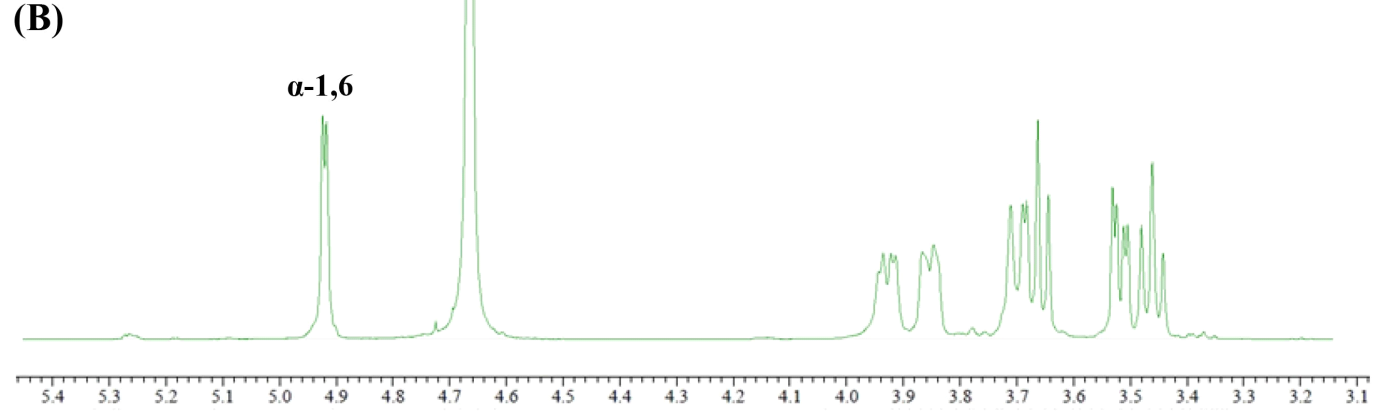

(C)

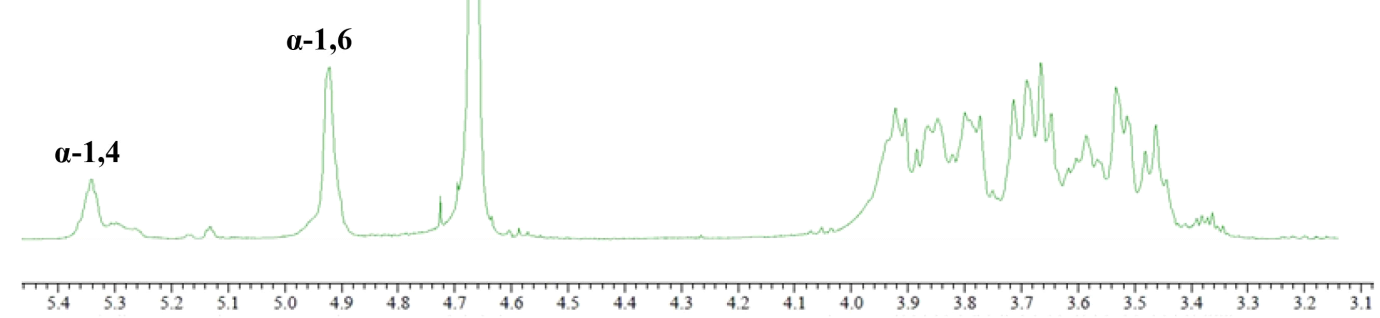

Fig. 7. ${ }^{1} \mathrm{H}-\mathrm{NMR}$ spectra of the isolated dextran from $G$. oxydans.

A, dextrin ( $\alpha-1,4$ linkage); B, dextran ( $\alpha-1,6$ linkage); C, isolated dextran from G. oxydans cultured media in glycerol and dextrin $5 \%$ containing $\mathrm{AAB}$ media.

입과 생성물의 분지결합도 측정 등 추가적 연구를 통해 배양 액 내 dextran 생성 최적화 및 회수가 필요할 것으로 보인다.

\section{요 약}

포도당의 주 사슬결합이 $\alpha-1,6$ 형태로 이루어져 있는 동종 다당체인 dextran은 유산균뿐만 아니라, 초산균에서 유래하는 dextran dextrinase(DDase)라는 당전이 효소작용에 의해 dextrin으로부터 합성되는 미생물 유래의 biopolymer이다. 본 연구에서는 DDase에 의해 당전이 활성이 있는 초산균을 다 양한 배지 조성에 따라 배양함으로써 dextran 합성에 효과적 인 배지 구성 조건을 탐색하고, 배지 내 생성된 다당류의 특 성을 조사하고자 하였다. 즉, glycerol 첨가 $(2 \%, \mathrm{v} / \mathrm{v})$ 유/무, maltodextrin 중합도 및 농도(1,5\%)에 따른 $G$. oxydans
ATCC 19357의 생육곡선, $\mathrm{pH}$, 산도, 환원당 및 점도 변화를 통하여 이화학적 특성을 분석하고, 각각의 배지에서 회수한 다당류의 구성당 패턴(HPAEC-PAD)및 결합형태( $\left.{ }^{1} \mathrm{H}-\mathrm{NMR}\right)$ 를 조사하였다. 그 결과, glycerol 및 maltodextrin 첨가군에 서 초산균 7 일째 배양 배지의 $\mathrm{OD}$ 값이 3 배 가량 증가하여 배지조성에 따른 생육 증진효과를 확인하였다. G. oxydans ATCC 19357의 배양 7일째 배지의 $\mathrm{pH}$ 는 2.97-3.45, 산도는 $0.39-0.69$ 로 나타났으며, 환원당은 1 일차에 급격히 감소한 후 지속적으로 감소하였다. dextrin $5 \%$ 첨가 배지 $(\mathrm{G}(+) \mathrm{AAB}+$ $5 \% \mathrm{MD} 1, \mathrm{G}(+) \mathrm{AAB}+5 \% \mathrm{MD} 2)$ 의 점도는 배양 기간에 따라 증가하여 pseudoplastic한 성질을 나타내어 고분자 다당류가 생성되었음을 유추할 수 있었다. 특히 $\mathrm{G}(+) \mathrm{AAB}+5 \% \mathrm{MD} 1$ 배지 배양액의 겉보기 점도는 $5.53 \pm 0.05 \mathrm{mPa} \cdot \mathrm{s}$ 로 $20 \%$ dextran 수용액과 유사한 수준이었다. 배양액 내 생성된 구성 
당류의 패턴을 분석한 결과, dextrin 첨가 배지의 구성당 패턴 과 달리 dextran과 유사한 패턴의 중합도가 높은 물질 peak가 관찰되었다. 이러한 다당류의 분자 간 결합 형태는 $\alpha-1,6$ glycosidic bond를 형성한 물질에서 나타나는 $4.9 \mathrm{ppm}$ 위치 에 chemical shift가 우세한 것으로 관찰되어, 첨가한 dextrin 이 초산균에 의해 dextran으로 생물 전환된 것을 확인하였다. 따라서 당전이 활성이 있는 초산균 배양 시 배지 구성으로 glycerol 및 5\% maltodextrin(D.E. 4.0-7.0, MD2)의 첨가는 G. oxydans ATCC 19357의 증식 및 dextran으로 전환을 촉 진함으로써 생물전환을 통한 dextran 제조에 효과적인 것으 로 사료된다.

\section{감사의 글}

본 연구는 농촌진흥청 국립농업과학원 농업과학기술 연구 개발사업(과제번호: PJ01417501)의 지원에 의해 이루어진 것 으로서 이에 감사드립니다.

\section{Conflict of interests}

The authors declare no potential conflict of interest.

\section{ORCID}

$\begin{array}{ll}\text { Ji Hye Jeong } & \text { https://orcid.org/0000-0001-9290-8355 } \\ \text { Ji Yeong Park } & \text { https://orcid.org/0000-0002-9927-3513 } \\ \text { Bo-Ram Park } & \text { https://orcid.org/0000-0001-5675-802X }\end{array}$

\section{References}

Bertrand E, Pierre G, Delattre C, Gardarin C, Bridiau N, Maugard T, Strancar A, Michaud P. Dextranase immobilization on epoxy $\mathrm{CIM}^{\circledR}$ disk for the production of isomaltooligosaccharides from dextran. Carbohydr Polym, 111, 707-713 (2014)

Brueckner R, Titgemeyer F. Carbon catabolite repression in bacteria: Choice of the carbon source and autoregulatory limitation of sugar utilization. FEMS Microbiol Lett, 209, 141-148 (2002)

De Muynck C, Pereira CSS, Naessens M, Parmentier S, Soetaert W, Vandamme EJ. The genus Gluconobacter oxydans: Comprehensive overview of biochemistry and biotechnological applications. Crit Rev Biotechnol, 27, 147-171 (2007)
Gaetgens C, Degner U, Bringer-Meyer S, Herrmann U. Biotransformation of glycerol to dihydroxyacetone by recombinant Gluconobacter oxydans DSM 2343. Appl Microbiol Biotechnol, 76, 553-559 (2007)

Hehre EJ, Hamilton DM. Bacterial conversion of dextrin into a polysaccharide with the serological properties of dextran. Proc Soc Exp Biol Med, 71, 336-339 (1949)

Hehre EJ. The biological synthesis of dextran from dextrins. J Biol Chem, 192, 161-174 (1951)

Im P, Han JH, Kim YC, Lee B, Kim MY, Chang Y, Yu $\mathrm{S}$, Lee Y. Effects of guar gum on quality of soft tofu stew sauce. J Korean Soc Food Sci Nutr, 44, 442-448 (2015)

Jang JK. Rheological property of biopolymer produced from Bacillus polymyxa YU-101. Food Eng Prog, 23, 94-103 (2019)

Jeong WS, Kim YR, Hong SJ, Choi SJ, Choi JH, Park SY, Woo EJ, Kim YM, Park BR. Carboxy-terminal region of a thermostable CITase from Thermoanaerobacter thermocopriae has the ability to produce long isomaltooligosaccharides. J Microbiol Biotechnol, 29, 1938-1946 (2019)

Kim BK, Suh MJ, Park JS, Park JW, Suh JW, Kim JY, Lee SY, Choi JK, Suh JW, Lee IA. Characterization and culture optimization of an glucosidase inhibitorproducing bacteria, Gluconobactor oxydans CK-2165. J Korean Academia-Industr Coop Soc, 13, 5179-5186 (2012)

Kim HJ, Park SH, Park CH. Studies on the production of vinegar from barley. Korean J Food Sci Technol, 17, 350-354 (1985)

Kooi ER, Grange L. Production of dextran-dextrinase. U.S. Patent No. 2,833,695 (1958)

Leathers TD. Dextran. Biopolymers, 5, 299-321 (2002)

Lee EB, Kim HY, Han GJ, Park BR. Preparation of isomaltooligosaccharides using puffed rice flour and evaluation of physicochemical properties. Korean J Food Preserv, 25, 229-236 (2018)

Lee SY, Kim JY, Shim CS. Rheological properties of biopolymer produced by alkali-tolerant Bacillus sp. Korean J Food Sci Technol, 28, 538-544 (1996)

Lindberg B, Svensson S. Structural studies on dextran from Leuconostoc mesenteroides NRRL B-512. Acta Chemica Scandinavica, 22, 1907-1912 (1968) 
Mao X, Wang S, Kan F, Wei D, Li F. A novel dextran dextrinase from Gluconobacter oxydans DSM-2003: Purification and properties. Appl Biochem Biotechnol, 168, 1256-1264 (2012)

Naessens M, Cerdobbel A, Soetaert W, Vandamme EJ. Dextran dextrinase and dextran of Gluconobacter oxydans. J Ind Microbiol Biotechnol, 32, 323-334 (2005b)

Naessens M, Cerdobbel A, Soetaert W, Vandamme EJ. Leuconostoc dextransucrase and dextran: Production, properties and applications. J Chem Technol Biotechnol, 80, 845-860 (2005a)

Naessens M, Vandamme EJ. Transglucosylation and hydrolysis activity of Gluconobacter oxydans dextran dextrinase with several donor and acceptor substrates. In: Biorelated Polymers, Springer, Boston, MA, USA, p 195-203 (2001)

Naessens M, Vercauteren R, Vandamme EJ. Three-factor response surface optimization of the production of intracellular dextran dextrinase by Gluconobacter oxydans. Process Biochem, 39, 1299-1304 (2004)

Netsopa S, Niamsanit S, Sakloetsakun D, Milintawisamai N. Characterization and rheological behavior of dextran from Weissella confusa R003. Int J Polym Sci, 2018, 5790526 (2018)

Pazur JH, Ando T. The isolation and the mode of action of a fungal transglucosylase. Arch Biochem Biophys, 93, 43-49 (1961)

Prust C, Hoffmeister M, Liesegang H, Wiezer A, Fricke WF, Ehrenreich A, Gottschalk G, Deppenmeier U. Complete genome sequence of the acetic acid bacterium Gluconobacter oxydans. Nat Biotechnol, 23, 195-200 (2005)

Purama RK, Goswami P, Khan AT, Goyal A. Structural analysis and properties of dextran produced by Leuconostoc mesenteroides NRRL B-640. Carbohydr Polym, 76, 3035 (2009)

Robyt JF, Walseth TF. Production, purification, and properties of dextransucrase from Leuconostoc mesenteroides NRRL B-512F. Carbohydr Res, 68, 95-111 (1979)

Sadahiro J, Mori H, Saburi W, Okuyama M, Kimura A. Extracellular and cell-associated forms of Gluconobacter oxydans dextran dextrinase change their localization depending on the cell growth. Biochem Biophys Res Commun, 456, 500-505 (2015)

Son BS, Park SK, Lee SW, Sung CK, Seo KI. Viscosity of exopolysaccharide from Xanthomonas sp. EPS-1. J Korean Soc Food Sci Nutr, 25, $53-57$ (1996)

Suzuki M, Unno T, Okada G. A kinetic study of an extracellular dextrin dextranase from Acetobacter capsulatum ATCC 11894. J Appl Glycosci, 47, 27-33 (2000)

Suzuki M, Unno T, Okada G. Simple purification and characterization of an extracellular dextrin dextranase from Acetobacter capsulatum ATCC 11894. J Appl Glycosci, 46, 469-473 (1999)

Tako M, Nagahama T, Nomura D. Some rheological properties of the viscous polysaccharide produced by coryneform bacteria strain C-8. J Agric Chem Soc Jpn, 51, 389-395 (1977)

Tizzotti MJ, Sweedman MC, Tang D, Schaefer C, Gilbert RG. New ${ }^{1} \mathrm{H}$-NMR procedure for the characterization of native and modified food-grade starches. J Agric Food Chem, 59, 6913-6919 (2011)

Vuillemin M, Grimaud F, Claverie M, Rolland-Sabate A, Garnier C, Lucas P, Monsane P, Dols-Lafargue M, Remaud-Simeon M, Moulis C. A dextran with unique rheological properties produced by the dextransucrase from Oenococcus kitaharae DSM 17330. Carbohydr Polym, 179, 10-18 (2018)

Wang T, Deng L, Li S, Tan T. Structural characterization of a water-insoluble $(1 \rightarrow 3)$ - $\alpha$-D-glucan isolated from the Penicillium chrysogenum. Carbohydr Polym, 67, 133137 (2007)

Yamamoto K, Yoshikawa K, Kitahata S, Okada S. Purification and some properties of dextrin dextranase from Acetobacter capsulatus ATCC 11894. Biosci Biotechnol Biochem, 56, 169-173 (1992)

Yamamoto K, Yoshikawa K, Okada S. Detailed action mechanism of dextrin dextranase from Acetobacter capsulatus ATCC 11894. Biosci Biotechnol Biochem, 57, 47-50 (1993)

Yamamoto K, Yoshikawa K, Okada S. Substrate specificity of dextrin dextranase from Acetobacter capsulatus ATCC 11894. Biosci Biotechnol Biochem, 58, 330-333 (1994) 